\title{
Factors Determining Z-score and Corporate Failure in Malaysian Companies
}

\author{
Nurul Izzaty Hasanah Azhar \\ Faculty of Administrative Science and Policy Studies \\ Universiti Teknologi Mara, Shah Alam, Malaysia \\ Email: msnurulizzatyhasanah@gmail.com \\ Norziana Lokman \\ Faculty of Administrative Science and Policy Studies \\ Universiti Teknologi Mara, Shah Alam, Malaysia \\ Email: norzi716@uitm.edu.my \\ Md. Mahmudul Alam* \\ School of Economics, Finance \& Banking \\ Universiti Utara Malaysia, Sintok, Kedah, Malaysia \\ Email: rony000@gmail.com \\ Jamaliah Said \\ Accounting Research Institute \\ Universiti Teknologi Mara, Shah Alam, Malaysia \\ Email: jamaliah533@uitm.edu.my \\ * corresponding author
}

\section{Citation Reference:}

Azhar, N.I.H., Lokman, N., Alam, M.M., \& Said, J. (2021) Factors Determining Z-score and Corporate Failure in Malaysian Companies. International Journal of Economics and Business Research, 21(3), 370-386. (online) http://dx.doi.org/10.1504/IJEBR.2021.114381

This is a pre-publication copy.

The published article is copyrighted by the publisher of the journal. 


\title{
Factors Determining Z-score and Corporate Failure in Malaysian Companies
}

\begin{abstract}
Predicting the sustainability of a business is crucial to prevent financial losses among shareholders and investors. This study attempts to evaluate the Altman model for predicting corporate failure in distressed and non-distressed Malaysian companies based on the data of financially troubled companies which are classified as Practice Note 17 (PN17) and matching similar non-PN17 companies during the period 2013 to 2017. This study utilizes panel ordinal and panel random effects regressions. Findings show that the liquidity, profitability, leverage, solvency, and efficiency ratios are negatively significantly associated with corporate failure and bankruptcy. The leverage ratio is determined to be the strongest indicator of bankruptcy, followed by profitability, liquidity, solvency, and efficiency ratios. The findings will help companies' management bodies implement suitable strategies to prevent further financial leakage, thereby ensuring continuous and sustainable return on investment and profits for investors and shareholders.
\end{abstract}

Keywords: Corporate Failure, Financial Distress, PN17 companies, Ratio analysis, Z-Score.

\subsection{Introduction}

Financial failure is defined as the inability of a company to pay its current liabilities or debts (Beaver, 1966; Zeytinoglu \& Akarim, 2013; Geng, Bose \& Chen, 2016; Ross, Westerfield \& Jaffe, 2018) and may lead to bankruptcy or liquidation. Financial distress in a company can adversely affect performance by giving rise to high leverage and low liquidity, efficiency, and profitability. Moreover, financial distress can affect a company's liquidity position, which is measured by the amount of working capital. Numerous highly leveraged companies are unable to renegotiate their debt agreement as a consequence of their inability to maintain liquidity. Thus, they may face the risk of restructuring, liquidation, acquisition, or being the target of a merger takeover (Andualem, 2015). As well, financial failure is closely linked to fraudulent financial reporting (Arshad, Iqbal \& Omar, 2015) because a company in financial distress tends to have an incentive to commit fraud. Thus, the financial failure of a company has severe consequences leading to corporate failure in the future.

Understanding the causes of corporate failure is crucial. Recognizing the symptoms of corporate failure as well as understanding its causes may help owners or senior management take measures in advance that can hinder or prevent bankruptcy. Therefore, a study on the prediction of corporate failure is important for ensuring that a company can survive and continue to operate over a long period. Early detection can help management supervise a company's working capital and capital structure efficiently and effectively, thereby minimizing costs associated with corporate failure (Ross et al., 2018). A company may be rescued and may avoid bankruptcy if corporate failure can be predicted early and accurately.

In Malaysia, the classification of PN17 companies (Practice Note 17) refers to generally financially troubled companies. The designation of a PN17 company is given by Bursa Malaysia to a company when it is either financially distressed or does not have a core business or has failed to meet minimum capital or equity and companies' shareholders' funds are less than $25 \%$ of their total paid-up capital. Furthermore a listed company will also be designated as the PN17 company if the receivers have been appointed to take control of the assets of the company and if an adverse opinion in the listed company's latest audited financial statements 
and its ability to continue as a going concern have been expressed by the auditors (Bursa Malaysia Listing Requirement, 2018).

Companies that fall within the definition of PN17 will need to submit their regularization plan to the Securities Commission and the Stock Exchange within 12 months to restructure and revive their company in order to maintain listing status on the stock exchange. There are many reasons for the changes in the status of listing companies on the Malaysian Stock Exchange. It may be due to changes in management, risk profile, management team's experience, foresight, financial appetite or over-gearing. Under these circumstances and following the Stock Exchange rules, affected companies will be removed from the official list of Bursa Securities, after the imposition of the suspension, and delisting procedures against the companies in the wake of their failure will be regularized.

Based on the above discussion, we use the term PN17 companies to refer to those companies that are known as corporate failures or financially failed companies. Non-PN17 companies, on the other hand, refer to financially sound companies. Bursa Malaysia takes a stringent view of breaches of the Stock Exchange Rules and Listing Requirements since these breaches have the potential to undermine investors' rights and level of protection. However, only a few studies on PN17 and non-PN17 Malaysian companies have been published owing to the limited financial and non-financial data available on such companies. Companies make a major contribution to a country's economy and people's incomes. Understanding the company's financial performance and position helps top management, shareholders, creditors and potential investors to make the appropriate decision. As such, there is a need for a sound prediction model to identify and predict how well a company will function well into the future.

Previous studies have used varying ratios to detect symptoms of financial distress and predict corporate failure (Sayari \& Mugan, 2017; Muhammad Sori \& Abd Jalil, 2009; Abdullah, Halim, Ahmad \& Rus, 2008). A company can reduce the risk of corporate failure if a consensus can be reached on which types of financial ratios are the best indicators for predicting corporate failure (Liang, Lu, Tsai \& Shih, 2016; Salamudin \& Ahmad, 2013). Moreover, financial ratio analysis is one of the practical tools used to track companies that are highly vulnerable to bankruptcy (Mohammed \& Kim-Soon, 2012). Liquidity, profitability, leverage, solvency, and efficiency ratios are the most common financial ratios used in corporate failure research (Abdullah, Halim, Ahmad \& Rus, 2008). However, empirical findings have presented mixed results, thereby making it difficult to ascertain which ratio can determine and predict corporate failure accurately (Ong, Yap \& Khong, 2011; Md Zeni \& Ameer, 2010). In addition, financial ratios used to predict corporate financial difficulties differ depending on the industry (Sayari \& Mugan, 2017).

The Altman Z-score model is the most common and effective tool used worldwide (Altman, 1968; Md Zeni \& Ameer, 2010; Arshad et al., 2015). For the last five decades, this model has remained the established tool for assessing companies' business performance. However, few current studies exist on the prediction of corporate failure, especially in the context of Malaysia. Prior to 2010, numerous studies predicting corporate failure were conducted, for example on the accounting fraud in the case of Enron and many others in the wake of the Global Financial Crisis. However, the findings of such studies may not be relevant owing to recent developments such as technological advances, globalization, and changes in accounting procedures and rules. Hence, this study seeks to use recent data to determine a predictor of corporate failure by using the Altman Z-score model. 
There are some limitations related to Z-score when it used to predict corporate failure. The computation of the Z-score used historical data which may be obsolete and irrelevant. Further, the data is only accurate as of the data that goes into it as such using Z-score may tempt the preparer of the financial statement to misrepresent the company's financial health. Finally, the Z-score value may not be useful for new companies with little earning or no earning capacity, regardless of their strong financial health, and they will score a low value (Hallas, 2020). Altman Z-score models also have too much focus on company assets (Paradi, Wilson and Yang, 2014). Thus, Z-score cannot be used as an absolute predictor of corporate failure. However, Zscores are a powerful metric to provide an unbiased assessment of a company's financial health (Hallas, 2020; Gowri and Sekar, 2014).

Previous studies have suggested that investors should keep a vigilant eye on their investments and consider checking their companies' Z-score regularly (Md Zeni \& Ameer, 2010). A deteriorating Z-score can signal impending trouble (Altman, 1968). Therefore, the Z-score can be used not only as a gauge of relative financial health but also as a predictor of financial distress. Arguably, the model can best be used as a quick assessment of financial health; however, a detailed analysis should be conducted if the score indicates a problem (Altman, 1968; Altman, 1977). Hence, this study contributes to the current literature on the prediction of corporate failure, especially on the subject of Malaysian companies. The findings will help the management of companies to implement suitable strategies to prevent further financial leakage and the regulatory bodies to determine and monitor the risky companies.

There are numerous artificial intelligence (AI) systems which have been developed and can accurately predict corporate failure. For example, Expert System (ES), Neural Networks, Self Organizing Map, Data Envelopment Analysis (DEA) and Multi-Layer Perception. However, all these so-called AI systems do have their flaws. Expert System (ES) is an artificial intelligence computer system that emulates the decision-making ability of a human expert. Application of ES areas includes classification, diagnosis, monitoring, control, design, scheduling and planning, and generation of options. Even though ES is powerful in predicting corporate failure, it has several limitations whereby the system has no common sense in making decisions and is unable to explain the logic and reasoning behind a decision (Appiah, Chizema and Arthur, 2015). A Neural Network (NN) is better than ES because it can adapt its criteria to match better the data it analyses. Similar to ES, NN is also unable to provide a clue as to why and how the problem identified can be solved. This is because the problem has to be translated into numerical values before being introduced to NN (Al-Haroot, 2016). Self Organizing Map can improve a model's reliability and accurately forecast the likelihood of corporate failure beyond the one year compared to other methods such as Neural Network, logistic regression and discriminant analysis (Jardin and Severin, 2011). Another tool - Data Envelopment Analysis (DEA) - aims to make classifications of corporate failure and sound (healthy) company. This tool makes it possible to compare efficiency between several units, units, departments, companies and tools, but it only measures relative efficiency, not maximum or the best efficiency (Paradi, Wilson and Yang, 2017; Pablo and Manuel, 2014). For these reasons, this study uses Altman's Z-score to assess the financial health of PN17 companies with matching non-PN17 companies.

This paper is organized into five sections. The next section reviews the relevant literature and explains the hypotheses development. Section 3 describes the research methodology, and Section 4 presents the key findings and analysis. The final section includes the discussion and concludes the study. 


\subsection{Literature Review and Hypotheses Development}

\subsection{Liquidity}

Liquidity is an important financial indicator that measures whether a company has the ability to meet its short-term liabilities without incurring undesirable losses (Ross et al., 2018). Liquidity risk may arise from the ineffective use of assets, which is highly challenging compared with other financial risks. According to Brigham and Ehrhardt (2014), the higher the liquidity ratio, which is measured by the current or quick ratio, the more able a company is to pay its obligations. This phenomenon exists because a company has a larger proportion of assets value relative to its liabilities value. Conversely, a low liquidity ratio generally indicates that a company's liabilities are greater than its assets, thereby suggesting that the company in question would be unable to pay off its obligations when they are due at that point. Although a low liquidity ratio indicates that a company is experiencing financial difficulties in meeting daily shortterm liabilities (Ma'aji, Abdullah \& Khaw, 2018), it does not necessarily mean bankruptcy for that company (Brigham \& Ehrhardt, 2014).

Yap, Yong, and Poon (2010) argued that liquidity and profitability ratios are most useful in predicting a company's success or failure. Wijekoon and Azeez (2015) likewise argued that liquidity is a significant predictor, and the authors' results found that the working capital to total assets ratio has an explanatory power to predict corporate failure. Md Zeni and Ameer (2010) confirmed that the quick ratio is a powerful tool for predicting corporate failure. Similarly, Megaravalli and Sampagnaro (2018) find in their analysis that liquidity ratio is one of the significant predictors of firm growth and default. Meanwhile, Ong, Yap, and Khong (2011) determined that all the five ratios, including the liquidity ratio, act as satisfactory predictors of financial distress in companies in Malaysia. Thus the following hypothesis is posited.

H1: The liquidity ratio has a positive relationship with the Z-score and a negative relationship with corporate failure.

\subsection{Profitability Ratio}

Income ratios are closely linked to profitability ratios, which sheds light on the overall effectiveness of management regarding returns generated by sales and investments (Ross et al., 2018). Retained earnings generally consist of a company's increasing net income less any net losses and declared dividends. In general, a firm with a poor profitability record may be regarded as potentially bankrupt (Altman, 1968). Md Zeni and Ameer (2010) suggested that monitoring distress in companies by using the profitability ratio is appropriate, as it can signal that a company is in trouble.

Brigham and Ehrhardt (2014) explained that the net income to total assets ratio is a profitability ratio that measures the net income produced by total assets during a period by comparing the net income with the average total assets. In other words, the return on assets ratio measures the efficiency of a company to manage its assets to produce profits during a certain time period. Appiah and Abor (2009) found out that the net profit margin is superior to the gross profit margin, in terms of its significant contribution to the $\mathrm{Z}$-score, in discriminating between failed and non-failed UK manufacturing companies. Mitroussi et al. (2016) state that profitability measures are closely associated with company failure. However, the latter slightly exceeds the former by using the univariate analysis. Similarly, Ong et al. (2011) determined that the 
profitability ratio is significantly associated with corporate failure. The profitability ratio is considered to be a critical feature of the financial ratio, which can effectively predict bankruptcy if used with a corporate governance indicator (Liang et al., 2016). For this reason the following hypothesis is developed based on the above discussion.

$\mathrm{H} 2$ : The profitability ratio has a positive relationship with the Z-score and a negative relationship with corporate failure.

\subsection{Leverage Ratio}

The debt to equity $(\mathrm{D} / \mathrm{E})$ ratio, which is essentially a leverage ratio, is one of the most frequently used ratios for evaluating a company's financial health. According to Brigham and Ehrhardt (2014), the D/E ratio provides a primary measure of a company's ability to meet its financing obligations as well as its financing structure regardless of whether it comes more from equity investors or more from debt financing. A high or increasing ratio indicates that a company is overly dependent on financing from creditors as opposed to capital provided by equity investors. This ratio is calculated by dividing the total assets of a firm with its earnings before interest and tax (EBIT) reductions (Brigham \& Ehrhardt, 2014). Essentially, the D/E ratio is a measure of the true productivity of a firm's assets, abstracting from any tax or leverage factors. Given that a firm's ultimate existence is based on the earning power of its assets, this ratio appears to be especially appropriate for studies on corporate failure.

Furthermore, this ratio is important because it is one of the factors considered by lenders. Lenders may be unwilling to extend further credit to a company if they perceive that this ratio is becoming uncomfortably high. This reaction is because aggressive leveraging practices is generally associated with high levels of financial risks. To make matters worse, a firm that depends heavily on debt may have volatile earnings resulting from additional interest expenses (Ma'aji et al., 2018), which result in low profits. Therefore, bankruptcy may occur when the cost of debts becomes too much for a company to handle.

Khaliq, Altarturi, Thaker, Harun, and Nahar (2014) revealed that determinants such as current and debt ratios can be used to predict bankruptcy. The authors' results showed that a significant relationship exists between variables and Z-scores that determine financial distress in government linked companies (GLC) in Malaysia. In addition, Ma'aji et al. (2018) found that debt ratio is positively related to corporate failure in small and medium-sized enterprises. Haider, Ou and Pettit (2019) confirm that debt ratio is an important factor in examining companies' financial performance and corporate failure. Furthermore, Amendola, Restaino, and Sensini (2011) investigated factors that influence financial distress in Italian companies based on three different market exit types, namely, bankruptcy, liquidation, and inactivity. These authors concluded that gearing has a negative relationship with inactive states of a company but a positive impact on the probability of a company becoming bankrupt. This finding indicated that factors influencing a company's financial distress differ depending on the probability of exit types. Thus, the following hypothesis is developed based on the above argument.

H3: The leverage ratio has a positive relationship with the Z-score and a negative relationship with corporate failure.

\subsection{Solvency Ratio}


The solvency ratio shows how much a firm's assets can decline in value (which is measured by the market value of equity) before liabilities exceed assets and the firm becomes insolvent (Altman, 1968). This ratio is measured by dividing the market value of equity by total liabilities. That is, the solvency ratio measures the amount of debt and other obligation expenses used in company business relative to the amount of owner equity invested in the business (Ross et al. 2018). In other words, the solvency ratio is an indicator of a business's ability to repay all financial obligations when all assets are sold as well as its ability to continue operating as a viable business after financial adversity occurs. This ratio is important for company owners and investors, as it shows the market's reaction to a company's financial position in some sense. Generally, the higher the value of the ratio, the better it is for a company. This ratio has been used repeatedly to predict corporate failure, as it appears to be one of the financial ratios for measuring the Altman Z-score.

Wang and Campbell (2010) used the Z-score of the original Altman model, which includes the market value of equity to total liabilities, as one of the predictors. The authors revealed that the model has a significant predictive ability. This ratio has likewise been included in the Zeta model, which is an improvement of the original Altman model. The Zeta model for assessing corporate bankruptcy risk, which was developed by Altman (1977), demonstrates considerably improved accuracy compared with the existing failure classification model. Nguyen and Vo (2019) consider that firms' solvency ratio is able to predict financial vulnerability. Liang et al. (2016) employed seven financial ratio categories and five corporate governance indicator categories for predicting bankruptcy in Taiwanese companies. The authors identified that apart from factors such as different ownership structure types, the solvency ratio is a major key factor that can predict bankruptcy. Hence, the following hypothesis is developed.

H4: The solvency ratio has a positive relationship with the Z-score and a negative relationship with corporate failure.

\subsection{Efficiency Ratio}

Ross et al. (2018) suggested that efficiency ratios can help companies' management teams assess how well it generates income by assessing the use of credit, inventory, and assets. Moreover, the efficiency ratio measures the current performance of a company. This ratio shows the rate at which a company collects money for its credit sales or the frequency of inventory turns in a given period. This ratio is an easy way to measure company ability and efficiency in managing its assets with reference to the revenue generated (Brigham \& Ehrhardt, 2014). The higher the ratio, the smaller the investment required to generate sales revenue and thus the higher the profitability of the company. Therefore, a company with a high total assets turnover ratio can operate with fewer assets compared with a less efficient competitor and thus requires less debt and equity to operate.

Ong et al. (2011) proved that five financial ratios are significant and useful in predicting corporate failure in Malaysia, namely, current asset turnover, asset turnover, days sales in receivables, cash flow to total debts, and total liabilities to total assets. Yang and Dimitrov (2017) developed a model to predict corporate failure by combining data envelopment analysis (DVA) and support vector machines (SVM). They detected a efficiency ratio which is significant for predicting corporate failure and bankruptcy. Alifiah et al. (2014) likewise argued that efficiency ratios help predict corporate failure, and their results found that the total asset turnover ratio can be used to predict financial distress among companies in the trading and 
services sector in Malaysia. Therefore, the following hypothesis is put forward.

H5: The efficiency ratio has a positive relationship with the Z-score and a negative relationship with corporate failure.

As seen in Figure 1 below, the independent variables used in this study are liquidity ratio, profitability ratio, leverage ratio, solvency ratio and efficiency ratio. Meanwhile, the dependent variable used in this analysis is corporate failure which is measured by $\mathrm{Z}$-score.

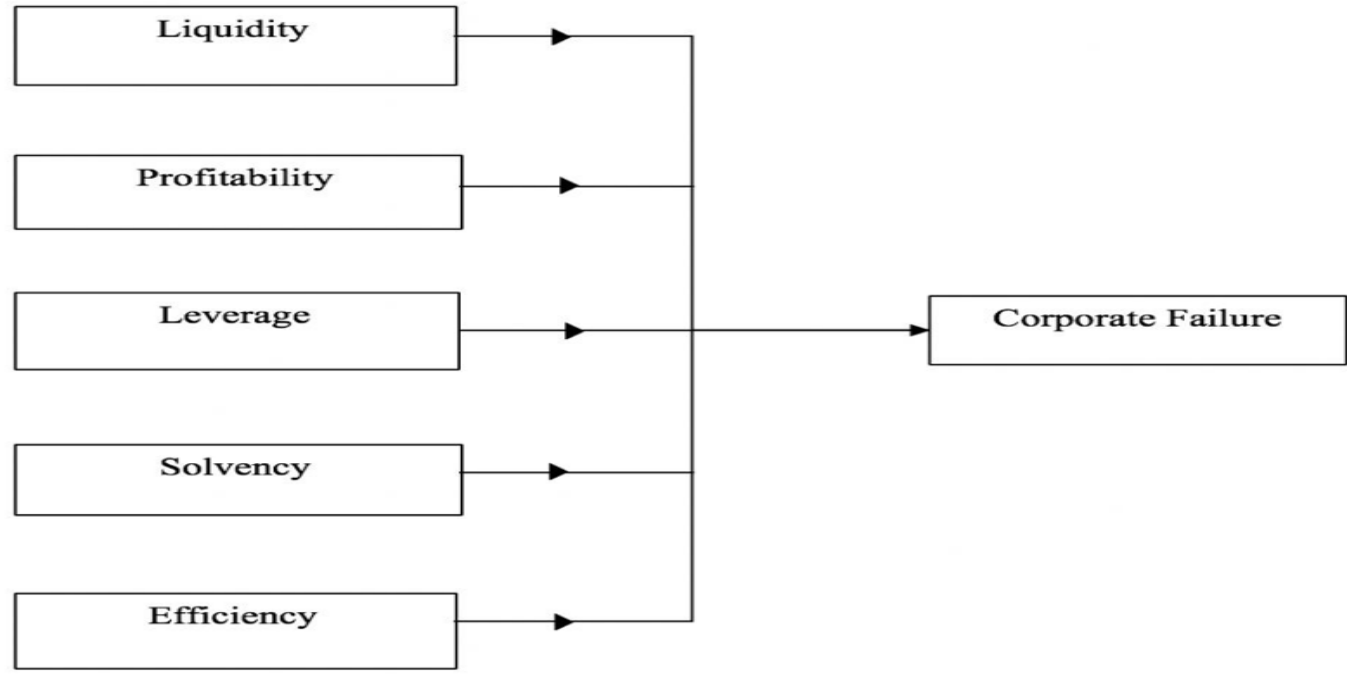

Figure 1: Conceptual framework for Predicting Corporate Failure

\subsection{Methodology}

The final sample in this study included only 14 PN17 companies and a matching sample of 14 non-PN17 companies, as seven (7) companies were excluded owing to the unavailability of data or changes in the calendar year for the period 2013-2017. The list of PN17 companies and nonPN17 companies involved in this study is presented in Appendix 1.

The sample of PN17 companies is selected based on the Bursa Malaysia database which is available as of 31 December 2017. The non PN17 companies are selected based on three criteria and the first is the annual report of the non-PN17 companies, which must be available from 2013-2017. For the second, the non-PN17 company must be operating in the same industry as the PN17 company sample. Thirdly, the chosen non-PN17 company has to be of the same size or comparable size as the PN17 company. The company size is measured by the total assets. In this case, if all the non-PN17 companies' total assets in the same industry are higher than the PN17 company, the one with the smallest assets value will be selected.

\subsection{Data}

Yearly data obtained from the Thomson Reuters Datastream were used for this study. As of October 31, 2018, 22 public listed companies from different sectors such as consumer products, trading and services, industrial products, finance, and properties were classified as PN17 
companies. These 22 PN17 companies were then matched with non-distressed companies by using the criteria of the same industry and closest asset size. The Thomson Reuters database was used to obtain a control sample of healthy companies from the same period. However, owing to the different nature of business in the finance sector, one PN17 finance company was specifically excluded from the consideration, as its business differs from the chosen set and would sufficiently generate a bias in the outcome of the analysis (Beaver, 1966). The final study sample involved 14 PN17 companies and a matching sample of 14 non-PN17 companies, as seven companies were excluded after the screening process owing to the unavailability of data or changes in the calendar year for the period 2013-2017 (see Appendix 1: List of PN17 Companies and Non-PN17 Companies).

Mohammed (2012) and Norliza and Maheran, (2015) state in regard to PN17 that the Malaysian Stock Exchange (Bursa Malaysia) classified some companies as PN17, specifically Practice Note 17/2005. They added those companies encountered financial distress and operational crisis and as such, default in loan interest and principal repayments. Auditors have expressed adverse opinions on the companies and their inability to provide a solvency declaration. The companies under the list have suspended or ceased all or a major part of their operations. Therefore, investors can easily discover if the companies have good fundamentals and procedures in place and feel it is safe to invest in them.

\subsection{Measurement of Variables}

Previous studies have determined corporate failure by using various corporate failure prediction models. The present study followed previous studies in the selection of financial ratios used in the 1968 Altman model to predict corporate failure as examined by Mohammed and Kim-Soon (2012) and Ishioma, Abdul, and Zubair (2015). The present study predicted corporate failure by using the liquidity, profitability, leverage, solvency, and efficiency ratios.

Table 1: Summary of Measurement

\begin{tabular}{|c|c|}
\hline Variables & Measurement \\
\hline Corporate failure & $\begin{array}{l}\text { Altman's model interpretation: } \\
\text { Z-score }=1.2 \mathrm{X} 1+1.4 \mathrm{X} 2+3.3 \mathrm{X} 3+0.6 \mathrm{X} 4+1.0 \mathrm{X} 5 \\
\text { Scale: } \\
\text { - A Z-score below } 1.8 \text { indicates that a firm is headed for } \\
\text { bankruptcy or the probability of being in financial distress. This } \\
\text { score is denoted by " } 3 . \text {." } \\
\text { - A Z-score between } 1.8 \text { and } 2.99 \text { is a statistical "grey area," which } \\
\text { indicates the possibility of bankruptcy; therefore, further } \\
\text { examination should be undertaken. This score is denoted by " } 2 . \text {." } \\
\text { - A Z-score above } 2.99 \text { indicates that a firm is unlikely to } \\
\text { experience bankruptcy and is considered "safe" based on financial } \\
\text { figures. This score is denoted by " } 1 . \text {." }\end{array}$ \\
\hline Liquidity (X1) & $\begin{array}{l}\text { Working capital / total assets } \\
=(\text { current assets }- \text { current liabilities }) /(\text { current assets }+ \text { fixed assets })\end{array}$ \\
\hline Profitability (X2) & $\begin{array}{l}\text { Retained earnings } / \text { total assets } \\
=(\text { retained earnings }) /(\text { current assets }+ \text { fixed assets })\end{array}$ \\
\hline Leverage (X3) & $\begin{array}{l}\text { EBIT } / \text { total assets } \\
=(\text { EBIT }) /(\text { current assets }+ \text { fixed assets })\end{array}$ \\
\hline
\end{tabular}


Solvency (X4)

Efficiency (X5)
Market value of equity / book value of total liabilities

$=$ (outstanding shares $\mathrm{x}$ share price $) /$ total liabilities

Sales / total assets

$=$ revenue $/$ (current assets + fixed assets)

\subsection{Model Specification}

This study ran the following two econometric models to draw inferences:

Corporate Failure $=($ Liquidity, Profitability, Leverage, Solvency, Efficiency $)$

Z-score $=($ Liquidity, Profitability, Leverage, Solvency, Efficiency $)$

Equation 1 measured the impact of liquidity, profitability, leverage, solvency, and efficiency on corporate failure. Given that corporate failure is an ordinal variable, the study ran the panel ordered regression for Equation 1. The objective of these models was to estimate the probability that an observation with particular characteristics will fall into one of the specific ordered categories. The ordinal regression was also tested according to the logit and probit models.

Equation 2 measured the impact of liquidity, profitability, leverage, solvency, and efficiency on the Z-score value. Given that the Z-score is a ratio variable, the study ran the fixed effects, random effects, and the pooled ordinary least squares (OLS) regressions for Equation 2. A fixed effects model is a statistical model in which model parameters are fixed or non-random quantities. However, a random effects model is a special case of a fixed effects model in which model parameters are random variables. Furthermore, the study ran the Hausman test and the Breusch-Pagan Lagrangian multiplier (LM) test to determine the appropriate model from the fixed effects, random effects, and pooled OLS models.

\subsection{Results and Analysis}

\subsection{Descriptive Analysis}

As expected, the descriptive statistics for the dependent variable in this study, which was corporate failure measured by the Z-score, showed that the mean for the PN17 companies was 1.44 , with a standard deviation of 2.19. The minimum and maximum values for the PN17 companies were between -4.35 and 10.07 , respectively. In contrast, the mean for the non-PN17 companies was 3.26, which signified a higher Z-score value compared with the PN17 companies (1.44). The standard deviation for the non-PN17 companies was 2.92. Additionally, the minimum and maximum values for the non-PN17 companies were between -0.979 and 12.637 , respectively.

Table 2: Descriptive Statistics for PN17 Companies and Non-PN17 Companies

\begin{tabular}{lclllllll}
\hline \multicolumn{3}{c}{ PN17 Companies } & \multicolumn{5}{l}{ Non-PN17 Companies } \\
\hline Variables & Min & Max & Mean & $\begin{array}{l}\text { Std. } \\
\text { Deviation }\end{array}$ & Min & Max & Mean & Std. \\
& & & & Deviation \\
\hline Z-score & -4.346 & 10.072 & 1.43990 & 2.191593 & -.979 & 12.637 & 3.25896 & 2.918427 \\
Liquidity & -.590 & .614 & .05782 & .297702 & -.442 & .930 & .18385 & .262162
\end{tabular}




\begin{tabular}{lllllllll} 
Profitability & -2.636 & .722 & -.18333 & .471947 & -.739 & .613 & .02093 & .312620 \\
Leverage & -.500 & .202 & -.06400 & .144728 & -.344 & .210 & .02213 & .093123 \\
Solvency & .114 & 16.065 & 2.09048 & 3.465048 & .109 & 20.705 & 3.80166 & 4.434616 \\
Efficiency & .000 & 1.388 & .58410 & .398857 & .071 & 2.883 & .65499 & .530944 \\
\hline
\end{tabular}

\subsection{Regression Analysis}

This study used an ordinal panel regression based on Equation 1, which included ordinal logit and ordinal probit models. Table 3 summarizes the findings in which all the independent variables in the logit and probit models were significant and had a negative impact on corporate failure, thereby indicating that the higher the value of these performance ratios, the lower the rate of corporate failure. Additionally, the highest probability derived from the leverage ratio, followed by the profitability, liquidity, efficiency, and solvency ratios.

Table 3: Output of Ordinal Logit and Ordinal Probit Models

\begin{tabular}{ccccc}
\hline Corporate Failure & \multicolumn{2}{c}{ Ordinal Logit } & \multicolumn{2}{c}{ Ordinal Probit } \\
\hline & Coefficient & P value & Coefficient & P value \\
\cline { 2 - 5 } Liquidity & $-15.24^{*}$ & 0.009 & $8.18^{*}$ & 0 \\
Profitability & $-15.00^{* *}$ & 0.012 & $7.80^{*}$ & 0.001 \\
Leverage & $-33.53^{* * *}$ & 0.075 & $16.39^{*}$ & 0.003 \\
Solvency & $-5.90^{* *}$ & 0.039 & $2.95^{*}$ & 0.001 \\
Efficiency & $-10.05^{* *}$ & 0.018 & $5.23 *$ & 0.001 \\
\hline$*, * *$, and *** represent that the variable is significant at the $1 \%, 5 \%$, and $10 \%$ levels, \\
respectively. \\
Note: The odd ratio for all the cases is more than 1.
\end{tabular}

Similarly, for Equation 2, which was based on the Hausman test and the Breusch-Pagan LM test, the random effects model was more appropriate than the fixed effects model and the pooled OLS model. All the coefficients were significant and had a positive impact on the Zscore value. Table 4 below summarizes the findings.

Table 4: Output of Random Effects Model

\begin{tabular}{cccc}
\hline Z-score & Coefficient & Std. Err. & P value \\
\hline Liquidity & $1.20^{*}$ & 0.000399 & 0.000 \\
Profitability & $1.40^{*}$ & 0.000308 & 0.000 \\
Leverage & $3.30^{*}$ & 0.0009345 & 0.000 \\
Solvency & $0.60^{*}$ & 0.0000272 & 0.000 \\
Efficiency & $1.00^{*}$ & 0.0002318 & 0.000 \\
Constant & -0.00 & 0.0002043 & 0.571 \\
\hline
\end{tabular}

* represents that the variable is significant at the $1 \%$ level

\subsection{Diagnostic Test}

Initially, this study ran the LM test to determine whether the appropriate model was the pooled OLS or the non-pooled OLS. Given that the $\varkappa^{2}$ was not significant, the appropriate model was the non-pooled OLS.

Table 5: Output of Breusch-Pagan LM Test 


\begin{tabular}{lll}
\hline & Var & Sd = sqrt (var) \\
\hline Z-score & 7.445722 & 2.728685 \\
$\mathrm{E}$ & $1.41 \mathrm{e}-06$ & .0011858 \\
$\mathrm{U}$ & $4.11 \mathrm{e}-08$ & .0002028 \\
\hline
\end{tabular}

Test: $\operatorname{Var}(\mathrm{u})=0 ; \operatorname{Chibar}^{2}(01)=0.02 ;$ Prob $>\operatorname{Chibar}^{2}=0.4400$

Based on the not-to-pool decision, this study further ran the Hausman test to identify the appropriate model from the fixed effects and random effects models. Since the $x^{2}$ was not significant, the appropriate model was the random effects model.

Table 6: Output of Hausman Test

\begin{tabular}{|c|c|c|c|c|}
\hline \multirow[t]{2}{*}{ Variables } & \multicolumn{2}{|c|}{ Coefficients } & \multirow{2}{*}{$\begin{array}{c}\text { (b-B) } \\
\text { Difference }\end{array}$} & \multirow{2}{*}{$\begin{array}{l}\text { Sqrt }\{\text { diag [V_b- } \\
\text { V_B] }\} \text { SE }\end{array}$} \\
\hline & (b) fe & (B) re & & \\
\hline Liquidity & 1.198782 & 1.199698 & -0.0009162 & .0007749 \\
\hline Profitability & 1.400438 & 1.400155 & 0.000283 & .0004016 \\
\hline Leverage & 3.299194 & 3.299558 & -0.0003643 & .0009082 \\
\hline Solvency & 0.6000054 & 0.6000179 & -0.0000126 & .000036 \\
\hline Efficiency & 0.9999301 & 1.000049 & -0.0001193 & .0004479 \\
\hline
\end{tabular}

$\mathrm{b}=$ consistent under Ho and Ha; obtained from xtreg

$\mathrm{B}=$ inconsistent under Ha and efficient under Ho; obtained from xtreg

Test: Ho: difference in coefficients is not systematic

Chi2 (5) $=(\mathrm{b}-\mathrm{B})^{\prime}\left[\left(\mathrm{V} \_\mathrm{b}-\mathrm{V} \_\mathrm{B}\right)^{\wedge}(-1)\right](\mathrm{b}-\mathrm{B})=2.53$

Prob $>\mathrm{Chi}^{2}=0.7726$

\subsection{Discussion and Conclusion}

Corporate bankruptcy is certainly a proven fact of business and the early detection of impending corporate distress is not an envied task. This study contributes to the existing literature on corporate failure prediction models by providing an understanding of the Malaysian context. This study concludes that the Altman Z-score model is a useful tool for predicting financial failure in public listed companies in Malaysia. This study leads to several conclusions. First, the financial health of the PN17 companies listed on the Malaysian Stock Exchange is poorer than that of the non-PN17 companies, as measured by the Altman Z-score model. The companies are analyzed by using the descriptive analysis to show the mean difference between the PN17 and non-PN17 companies. Results show a significantly large difference between the two sets of companies, specifically, that the non-PN17 companies have positive means, whereas the failed companies have negative means. This study likewise proves that not all PN17 companies are financial failures by separating financial-failure and nonfinancial-failure companies based on the Z-score computation for each company.

Based on the logistic regression, all the independent variables (liquidity, profitability, leverage, solvency, and efficiency ratios) are satisfactory predictors of corporate failure in PN17 companies. The leverage ratio is observed to have the highest likelihood of providing adequate and early signals on corporate financial difficulty, followed by the profitability, liquidity, efficiency, and solvency ratios. This finding suggests that all five ratios are important factors for measuring financial health and predicting the possibility of corporate failure. An interesting observation related to the logit and probit regression models is that all the financial ratios have a positive and significant association with corporate failure (Z-score). However, the ordinal 
logit model provides better results compared with the probit model. Consequently, the results of the study support all the hypotheses proposed in section 2 above.

One main limitation of the research is that it used financial data but ignored non-financial data such as corporate governance and strategic and forward-looking information, which may be useful to predict corporate failure. Moreover, the generalization of the research is limited because the study was based on Malaysian companies, which have different economic, political, social, and cultural characteristics compared with other countries. The application of the Z-score in this study may present another limitation of this study. The application of artificial intelligence computer systems such as Expert System, Neural Networks and Data Envelop Analysis in future research may help predict corporate failure accurately if the study has a large sample. Future research on this topic may investigate the above limitations to extend the application and generalization of their findings.

Companies' senior management, shareholders and investors need to assess the financial health of the organization and predict its likelihood of surviving. Results of the Z-score will help a company to strategize how the company can survive. In the case of this study, the PN17 companies need to reduce their leverage ratio to a more appropriate value by reducing their dependence on short-term debts. PN17 companies also need to enhance their profitability by maximizing their sales and operating incomes. The company should also manage adequate working capital in order to improve the efficiency of its assets. If this is done appropriately, the chances for the company being sustainable are higher. Being able to predict corporate failure is one way to ensure that a company will be able to prosper economically and remain socially viable in its provision of employment and continue to operate well into the future.

\section{References}

Abdullah, N.A.H., Halim, A., Ahmad, H. \& Rus R.M. (2008). Predicting corporate failure of Malaysia's listed companies: comparing multiple discriminant analysis, logistic regression and hazard model. International Journal of Finance and Economics, 15, 201217.

Al-Hroot, Y. (2016). A Comparison of Jordanian Bankcruptcy models: Multilayer Perceptron Nueral Network and Discriminant Analysis. Journal of International Business Research, 9(12), 121-130.

Alifiah, M.N., Salamudin, N. \& Ahmad, I. (2013). Prediction of financial distress companies in the consumer products sector in Malaysia. Jurnal Teknologi (Social Sciences), 64(1), 85-91.

Altman, E.I., Halderman, R., \& Narayana, P. (1977). Zeta Analysis: A new model to identify bankruptcy risk corporation. Journal of Banking and Finance, 32, 29-54.

Altman, E.L. (1968). Financial ratios, discriminant analysis and the prediction of corporate bankruptcy. Journal of Finance, 23(4), 589-609.

Amendola, A., Restaino, M., \& Sensini, L. (2015). An analysis of the determinants of financial distress in Italy: A competing risks approach. Review of Economics \& Finance, 37, 3341.

Amir, H.R. (2 September, 2018). More listed firms facing distress? New Straits Times. Retrieved from https://www.nst.com.my/business/2018/09/407311/more-listed-firmsfacing- distress. (Accessed on 17 June 2019)

Andualem, U. (2015). Determinants of Financial Distress in Manufacturing Firms of Ethiopia. Research Journal of Finance and Accounting, 6(17), 9-17. 
Appiah, K., Chizema, A. and Arthur, J.Predicting corporate failure: a systematic literature review of methodological issues. International Journal of Law and Management, 57(5), 461-485.

Appiah, K.O., \& Abor, J. (2009). Predicting corporate failure: some empirical evidence from the UK. Benchmarking: An International Journal, 16(3), 432-444.

Arshad, R., Iqbal, S.M., \& Omar, N. (2015). Prediction of Business Failure and Fraudulent Financial Reporting: Evidence from Malaysia. Indian Journal of Corporate Governance, 8(1) 34-53.

Azril, A. (23 August, 2018). How financially-distressed Utusan Can Survive, According to Former Staff, Media Experts. Malay Mail. Retrieved from https://www.malaymail.com/s/1665133/how-financially-distressed-utusan-can- surviveaccording-to-former-staff-med. (Accessed on 17 June 2019)

Beaver, W.H. (1966). Financial ratios as predictors of failure. Journal of Accounting Research, 4, 71-111.

Brigham, E.F., \& Ehrhardt, M.C. (2014). Financial Management: Theory \& Practice (15th ed.). USA: Cengage Learning.

Bursa Malaysia Listing Requirements (2018). http://www.bursamalaysia

Geng, R., Bose, I., \& Chen, X. (2014). Prediction of financial distress: An empirical study of listed Chinese companies using data mining. European Journal of Operational Research, 63, 59-67.

Gowri, M. \& Sekar, M. (2014). Assessing the financial health of selected automobile companies in india: A Quantitative approach using the $\mathrm{Z}$ score multi discriminant financial analysis. Great Lakes Herald, 8(1), 33-45.

Haider, J., Ou, Z., \& Pettit, S. (2019). Predicting corporate failure for listed shipping companies. Maritime Economics \& Logistics, 21(3), 415-438.

Hallas, N. (2020). Altman Z-Score as an indicator of financial health. Audit Analytics Accounting Quality Risk and Bankruptcies database. Posted in AQRM, Quality of Earnings.

Ishioma, O., Abdul, B., \& Zubair, H. (2015). Bankruptcy prediction using Altman Z- score model: a case of public listed manufacturing companies in Malaysia. International Journal of Accounting and Business Administration, 3(2), 178-186.

Jardin, P. \& Severin, E. (2011). Predicting corporate bankruptcy using a self-organizing map: An empirical study to improve the forecasting horizon of a financial failure model. Decision Support Systems, 51(3), 701-711.

Khaliq, A., Altarturi, B.H.M, Thaker, H.M.T., Harun, M.Y., \& Nahar, N. (2014). Identifying financial distress firm: A case study of Malaysia's Government Linked Companies (GLC). International Journal of Economics, Finance and Management, 3(3), 141-150.

Liang, D., Lu C.C., Tsai C.F., \& Shih G.A. (2016). Financial ratios and corporate governance indicators in bankruptcy prediction: A comprehensive study. European Journal of Operational Research, 252, 561-572.

Ma'aji, M.M, Abdullah, N.A.H., \& Khaw, K.L.H. (2018). Predicting financial distress among SMEs in Malaysia. European Scientific Journal, 14(7), 1857-7881.

Md. Zeni, S., \& Ameer, R. (2010). Turnaround prediction of distress companies: Evidence from Malaysia. Journal of Financial Reporting and Accounting, 8(2), 143-159.

Megaravalli, A. V., \& Sampagnaro, G. (2018). Firm age and liquidity ratio as predictors of firm growth: evidence from Indian firms. Applied Economics Letters, 25(19), 1373-1375.

Mitroussi, K., Abouarghoub, W., Haider, J. J., Pettit, S. J., \& Tigka, N. (2016). Performance drivers of shipping loans: An empirical investigation. International Journal of Production Economics, 171, 438-452. 
Mohammed, A. A. E. (2012). Financial situation of PN17 companies listed in the Malaysian stock exchange (Doctoral dissertation, Universiti Tun Hussein Onn Malaysia).

Mohammed, A.A.E., \& Kim-Soon, N. (2012). Using Altman's model and current ratio to assess the financial status of companies quoted in the Malaysian stock exchange. International Journal of Scientific and Research, 2(7), 1-11.

Muhammad Sori, Z. \& Abd Jalil, H. (2009). Financial ratios, discriminant analysis and the prediction of corporate distress. Journal of Money, Investment and Banking, 11, 5-15.

Nguyen, D. K., \& Vo, D. T. (2019). Enterprise risk management and solvency: The case of the listed EU insurers. Journal of Business Research. Available at https://www.sciencedirect.com/science/article/abs/pii/S0148296319305594

Norliza, M. Y., \& Maheran, M. J. (2015). Forecasting the Probability of Default of PN17 Company using KMV-Merton Model. International Journal of Applied Mathematics \& Statistics, 53(5), 103-108.

Ong S.W., Yap V.C., Khong R.W.L. (2011). Corporate failure prediction: a study of public listed companies in Malaysia. Managerial Finance, 37(6), 553-564.

Pablo de Llano Monelos \& Manual Rodriguez Lopez. (2014). DEA as a business failure prediction tool application to the case of galician SMEs. Contaduria y Administracion, 59(2) 65-96. https://doi.org/10.1016/50186-1042(14)71255-0

Paradi, J. C., Wilson, D'Andre., \& Yang, X. (2017). Data envelopment analysis of corporate failure for non-manufacturing firms using a slacks-based measure. Journal of Service Science and Management, 7, 277-290. Viewed on 26 March 2020 http://dx.doi.org/10.4236/jssm.2014.74025

Ross, S.A., Westerfield, R., \& Jaffe, J.F. (2018). Corporate Finance, (6 $6^{\text {th }}$ ed.). New York: McGraw-Hill.

Sayari, N. \& Mugan, C.S. (2017). Industry specific financial distress modelling. Business Research Quarterly, 20, 45-62.

Wang, Y., \& Campbell, M. (2010). Business failure prediction for publicly listed companies in China. Journal of Business and Management, 16(1), 75-89.

Wijekoon, N., \& Azeez, A.A. (2015). An integrated model to predict corporate failure of listed companies in Sri Lanka. International Journal of Business and Social Research, 5(7), 01-14.

Yang, X., \& Dimitrov, S. (2017). Data envelopment analysis may obfuscate corporate financial data: using support vector machine and data envelopment analysis to predict corporate failure for nonmanufacturing firms. INFOR: Information Systems and Operational Research, 55(4), 295-311.

Yap, B.C.F, Yong, D.G.F., \& Poon, W.C. (2010). How well do financial ratios and multiple discriminant analysis predict company failures in Malaysia? International Research Journal of Finance and Economic, 54, 166-175.

Zeytinoglu, E., \& Akarim, Y.D. (2013). Financial failure prediction using financial ratios: an empirical application on Istanbul Stock Exchange. Journal of Applied Finance \& Banking, 3(3), 107-116. 


\section{Author's Biography:}

Nurul Izzaty Hasanah Azhar is currently an Assistant Company Secretary at Aeon Vantage Advisory Sdn Bhd. She completed Master of Corporate Administration at the Faculty of Administrative Science and Policy Studies of Universiti Teknologi MARA.

Norziana Lokman is an Associate Professor of Faculty of Administrative Science and Policy Studies and currently attached with Accounting Research Institute at Universiti Teknologi MARA as a Fellow. She is also a Fellow member of the Malaysian Institute of Chartered Secretaries and Administrators (MAICSA). Her main research interests are corporate disclosure, corporate governance, corporate integrity, corporate sustainability and accountability.

Dr. Md. Mahmudul Alam is an Associate Professor of Finance at Universiti Utara Malaysia. $\mathrm{He}$ is also an Associate Fellow at Centre for Asian Climate and Environmental Policy Studies (Canada) and University Technology MARA (Malaysia). He has awarded the AFFP Research Fellowship from FS-UNEP Centre (Germany) and recognized by the BDRC (USA) as one of the "Top Bangladesh Development Researchers of the Millennium". He obtained his $\mathrm{PhD}$ and Master's degrees from National University of Malaysia. To date he has published 130+ journal articles and presented $80+$ articles at conferences. His research areas include sustainable finance, sustainable development, ecological economics, financial economics, fintech, and Islamic finance and economics.

Prof. Dr. Jamaliah Said is currently the Deputy Director of Accounting Research Institute, Universiti Teknologi MARA. She has published 100+ journal articles and presented 100+ articles in conferences. She is the managing editor of two eminent journals - Malaysian Accounting Review and Asia Pacific Management Accounting Review. Her main research interests are fraud, governance, accountability, and strategic management. 
Appendix 1: List of PN17 Companies and Matching Non-PN17 Companies

\begin{tabular}{|c|c|c|c|c|c|}
\hline No. & PN17 Companies & $\begin{array}{l}\text { Total Assets } \\
\text { (RM) }\end{array}$ & Industry & $\begin{array}{l}\text { Matched Non-PN17 } \\
\text { Companies }\end{array}$ & $\begin{array}{l}\text { Total Assets } \\
\text { (RM) }\end{array}$ \\
\hline 1 & Amtek Holdings Bhd & $36,436,000$ & $\begin{array}{l}\text { Textiles, apparel \& } \\
\text { luxury goods }\end{array}$ & Oceancash Pacific Bhd & $104,734,270$ \\
\hline 2 & Berjaya Media Bhd & $33,011,000$ & Media & Asian Media Group Bhd & $28,057,750$ \\
\hline 3 & Daya Materials Bhd & $461,212,770$ & Construction \& engineering & Ireka Corp Bhd & $483,790,150$ \\
\hline 4 & EKA Noodles Bhd & $5,638,310$ & Food products & Hwa Tai Industries Bhd & $63,898,530$ \\
\hline 5 & HB Global Ltd & $293,679,937$ & Food products & Cocoaland Holdings Ltd & $293,895,840$ \\
\hline 6 & Kuantan Flour Mills Bhd & $15,243,960$ & Food products & Green Ocean Corp Bhd & $37,855,410$ \\
\hline 7 & Multi-sport Holdings Ltd & $16,160,000$ & $\begin{array}{l}\text { Textiles, apparel \& } \\
\text { luxury goods }\end{array}$ & G3 Global Bhd & $85,407,110$ \\
\hline 8 & Stone Master Corp Bhd & $49,635,000$ & Building products & Able Group Bhd & $50,150,000$ \\
\hline 9 & Sumatec Resources Bhd & $853,863,970$ & Oil, gas \& consumable fuels & KUB Malaysia Bhd & $549,100,000$ \\
\hline 10 & TH Heavy Engineering Bhd & $1,025,535,120$ & Energy equipment $\&$ services & Scomi Energy Services Bhd & $1,027,795,000$ \\
\hline 11 & Utusan Melayu (Malaysia) Bhd & $423,950,480$ & Media & PUC Bhd & $200,018,700$ \\
\hline 12 & YFG Bhd & $53,625,610$ & $\begin{array}{l}\text { Constructi } \\
\text { on \& } \\
\text { engineerin } \\
\mathrm{g}\end{array}$ & LFE Corp Bhd & $59,821,000$ \\
\hline 13 & Bertam Alliance Bhd & $274,296,160$ & $\begin{array}{l}\text { Real estate management \& } \\
\text { development }\end{array}$ & Rapid Energy Berhad & $294,175,000$ \\
\hline 14 & Malaysia Pacific Corp Bhd & $499,993,000$ & $\begin{array}{l}\text { Real estate management } \\
\& \text { development }\end{array}$ & Sapura Resources Bhd & $492,891,000$ \\
\hline
\end{tabular}

